This article was downloaded by: [Stiftung Alfred-Wegener-Inst $f$ Pol]

On: 9 December 2009

Access details: Access Details: [subscription number 908424214]

Publisher Taylor \& Francis

Informa Ltd Registered in England and Wales Registered Number: 1072954 Registered office: Mortimer House, 3741 Mortimer Street, London W1T 3JH, UK

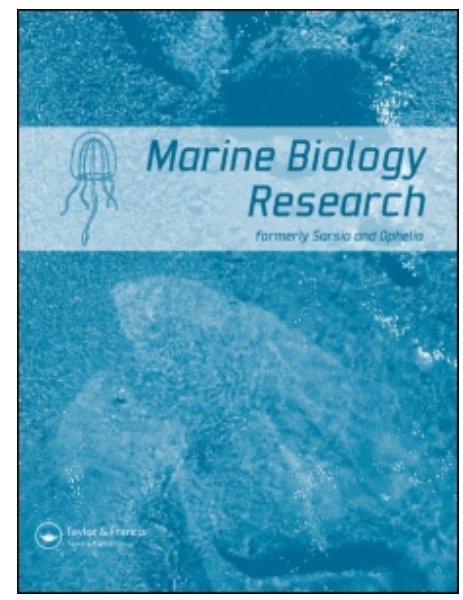

\title{
Marine Biology Research
}

Publication details, including instructions for authors and subscription information:

http://www.informaworld.com/smpp/title $\sim$ content=t713735885

\section{Vertical positioning and swimming performance of lobster larvae} (Homarus gammarus) in an artificial water column at Helgoland, North

\section{Sea}

Isabel Schmalenbach ${ }^{\text {a }}$; Friedrich Buchholz ${ }^{\text {a }}$

${ }^{a}$ Biologische Anstalt Helgoland, Stiftung Alfred-Wegener-Institut für Polar- und Meeresforschung,

Helgoland, Germany

First published on: 18 November 2009

To cite this Article Schmalenbach, Isabel and Buchholz, Friedrich(2010) 'Vertical positioning and swimming performance of lobster larvae (Homarus gammarus) in an artificial water column at Helgoland, North Sea', Marine Biology Research, 6: 1, 89 - 99, First published on: 18 November 2009 (iFirst)

To link to this Article: DOI: $10.1080 / 17451000902810769$

URL: http://dx.doi.org/10.1080/17451000902810769

\section{PLEASE SCROLL DOWN FOR ARTICLE}

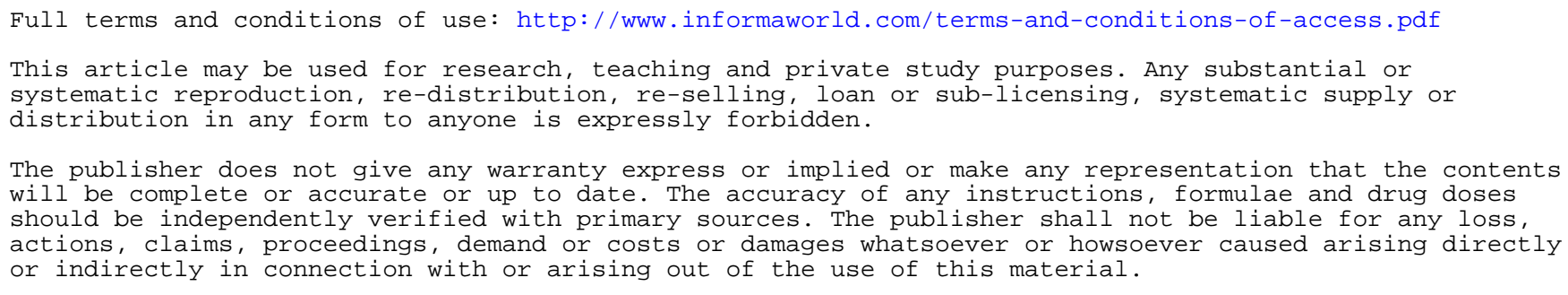

The publisher does not give any warranty express or implied or make any representation that the contents will be complete or accurate or up to date. The accuracy of any instructions, formulae and drug doses should be independently verified with primary sources. The publisher shall not be liable for any loss, actions, claims, proceedings, demand or costs or damages whatsoever or howsoever caused arising directly or indirectly in connection with or arising out of the use of this material. 


\title{
Vertical positioning and swimming performance of lobster larvae (Homarus gammarus) in an artificial water column at Helgoland, North Sea
}

\author{
ISABEL SCHMALENBACH* \& FRIEDRICH BUCHHOLZ \\ Biologische Anstalt Helgoland, Stiftung Alfred-Wegener-Institut für Polar- und Meeresforschung, Helgoland, Germany
}

\begin{abstract}
The vertical distribution and swimming ability of the three larval stages (Zoea I, II, and III) of Homarus gammarus were determined in laboratory experiments. In an artificial water column, newly hatched larvae were positively phototactic to white light at intensities near $0.6 \mu \mathrm{mol} \mathrm{m} \mathrm{m}^{-2} \mathrm{~s}^{-1}$. The positive phototactic behaviour decreased with increasing larval age and stage. Accordingly, older larvae were mostly distributed away from the light source in deeper layers and near the bottom. The measured vertical swimming speed of newly hatched larvae was $4.6 \pm 0.5 \mathrm{~cm} \mathrm{~s} \mathrm{~s}^{-1}$. Lobster larvae were positively rheotactic and thus able to swim against the current direction. The horizontal swimming ability of the larvae increased with stage from $0.7 \pm 1.0 \mathrm{~cm} \mathrm{~s}^{-1}$ (Zoea I) to about $1.5 \pm 0.9 \mathrm{~cm} \mathrm{~s}^{-1}$ (Zoea II) and $2.2 \pm 0.7 \mathrm{~cm} \mathrm{~s}$ (Zoea III). Implications for the persistence of the small, isolated lobster population around the island of Helgoland are discussed.
\end{abstract}

Key words: Homarus gammarus, larvae, North Sea, phototaxis, rheotaxis

\section{Introduction}

Stocks of European lobsters (Homarus gammarus Linnaeus, 1758) are the basis for important fisheries in Scotland, Norway (Van der Meeren \& Tveite 1998), England and Wales (Bannister 1986), France, Ireland (Browne et al. 2001; Tully et al. 2006), Sweden, Denmark and Spain (see Dow 1980). Within the past 70 years, total annual European landings have varied between 1700 and 3500 tons (Fishery Statistics 1950-2006). Along the German coast, the European lobster is restricted to the rocky subtidal zone of the island of Helgoland (German Bight, North Sea). Here, the local lobster fishery was important during the 1920s and 1930s and yielded around 38 tons per annum, until a severe decline in population size occurred in the 1960s (Klimpel 1965; Goemann 1990). To date, the lobster stock has not recovered, and annual landings remain very low but constant at about 200 lobsters per year (Deutscher Fischereiverein 1980-2007). The reasons for the collapse of the Helgoland stock are not known in detail, but may include habitat destruction by the bombing of the island during and after the Second World War, extensive fishing pressure in the 1950s and 1960s, and anthropogenic pollution of the North Sea waters by oil spills, chemicals and industrial wastes which increased strongly in the late 1960s (Klimpel 1965; Anger \& Harms 1994; Harms et al. 1995; Walter et al. 2008). Legislative regulations from 1981 and 1999 may have prevented a complete extinction of the local population at Helgoland, but until today did not substantially support the population's recovery (Ministerium für Landwirtschaft 1981, 1999).

The subtidal cliffs of Helgoland at an area of about $33 \mathrm{~km}^{2}$ are located 45 miles offshore in the German Bight, and the maximum depth of the Helgoland hard-bottom area reaches $24 \mathrm{~m}$. The local lobster population is geographically and ecologically isolated from similar hard-bottom areas and from neighbouring populations in Norway and Britain by some hundred miles of sandy or muddy bottoms (Ulrich et al. 2001). The island is exposed

^Correspondence: Isabel Schmalenbach, Biologische Anstalt Helgoland, Stiftung Alfred-Wegener-Institut für Polar- und Meeresforschung, 27498 Helgoland, Germany. E-mail: Isabel.Schmalenbach@awi.de

Published in collaboration with the University of Bergen and the Institute of Marine Research, Norway, and the Marine Biological Laboratory, University of Copenhagen, Denmark 
to strong tidal currents and wind impact, which lead to variations in water level and current speeds (Hickel 1972).

The missing recovery of the Helgoland lobster population may have been caused by the size of the population having become subcritical, and thus leading to continuous larval recruitment failure, caused by the drift of larvae away from the favourable rocky habitat of Helgoland by the local currents to such an extent that a larger stock could not be sustained any more. Various larval recruitment mechanisms have been documented for decapod crustacean larvae (Johnson 1960; Makarov 1969; Sandifer 1973) being dependent on factors as water depth, temperature - including climatic change, currents, immigration of ecological competitors and fishing pressure (Ennis 1983; Harding et al. 1983). Ennis (1983) described three possible conditions for larval settlement. First, 'larvae maintain their position near parental grounds during larval development'; second, 'larvae relocate parental grounds when ready to settle'; and third, 'larvae are carried passively by currents and their presence near suitable bottom when settling is fortuitous'. In view of these explanations, the continuing recruitment failure in the Helgoland lobster population may be demonstrated by very low numbers of larvae found in the field. In vertical plankton hauls of the Helgoland-Road time-series on meso- and macrozooplankton (Greve et al. 2004), lobster larvae were always very rare, e.g. in 2005 only three Zoeae of stage I were caught. This probably reflected the decline of the lobster stock and the ensuing low density of ovigerous females at the rocky bottom of Helgoland. Field studies about the temporal and spatial distribution of lobster larvae of $H$. americanus (H. Milne Edwards, 1837) are numerous (e.g. Templeman 1937; Harding et al. 1987), whereas only few studies on larvae of $H$. gammarus exist (Nichols \& Lawton 1978; Tully \& Ó Céidigh 1987). Larvae of $H$. americanus of all stages were found in large numbers in the plankton (Templeman 1937; Scarratt 1964). In contrast, larvae of $H$. gammarus are generally rare in the plankton, and most commonly the first and the fourth larval stages were found (Dunn \& Shelton 1983; Minchin 1984). Nichols (1984) mostly found the first larval stage of H. gammarus at the sea surface, and Ennis (1973) suggested that older larvae may disperse near the bottom and thus may be unavailable to plankton nets. However, Nichols (1984) confirmed that before 1976 only few larvae were recorded in the coastal waters of Europe generally, but being attributable to methodological inadequacies and the lack of knowledge about the occurrence and behaviour of larvae.

The larval development of the European lobster comprises three Zoea stages and one post-larval stage which were morphologically described by Nichols \& Lawton (1978). The locomotion ability of larvae changes during their larval development (Ennis 1995) and the major swimming appendages of the pelagic larvae are the exopodite branches of the third maxillipeds, the chelipeds and the four pairs of pereipods (Neil et al. 1976). By beating of the exopodites, the larvae carry forward, backwards or upwards; when their motion ceases, however, the larvae sink towards the bottom (Hadley 1908). The distribution of larvae is controlled by environmental factors such as currents systems, pressure, the lightdark regime, temperature, predators, and food abundance; and by behavioural components such as swimming ability and the active orientation to these environmental cues (Ennis 1983; Hudon \& Fradette 1993). Light is known to be important in the depth regulation of crustacean larvae (Forward 1989). In 2008, in Helgoland waters, only few larvae of stage I were found at the sea surface at night by light-catch (Schmalenbach, personal observation). In previous experiments, larvae oriented through perception of hydrostatic pressure and showed specific phototactic (Ennis 1973) and rheotactic behaviour (Ennis 1986). Hadley (1908) described phototactic responses of larvae of $H$. americanus and found that larvae changed their phototactic behaviour both within and between each stage. Mileikovsky (1973) summarized the larval swimming speed of bottom invertebrates with different methods employed. Generally, the pronounced swimming ability in larvae plays an important role to maintain position in currents (Mileijovsky 1973; Ennis 1986).

Due to the unavailability of larvae in the field, a laboratory study was designed to give insight how lobster larvae move in light fields and in currents to help to interpret larval behaviour in selection for an optimal habitat for survival and growth in a restricted area like around the island of Helgoland. Accordingly, we observed the response to light and currents of each Zoea stage (Zoea I, II, and III) to determine (1) the vertical distribution of larvae at different light-dark regimes, (2) their sinking rate, (3) their vertical swimming speed, and (4) their horizontal swimming ability to persist against currents. The data and results of our study on the behaviour of larvae in relation to the specific geographical region can be applied further in models forecasting the recruitment mechanisms of a local lobster population here and in general in order to 
assess conditions and chances for successful recruitment. On these grounds, further management procedures may be decided on to establish and conserve sustainability in lobster fishery.

\section{Materials and methods}

\section{Origin of larvae and maintenance}

The study was carried out during summer 2007 at the Marine Station on Helgoland. Berried female lobsters (Homarus gammarus) (mean total length: $32 \mathrm{~cm}$, mean weight: $1115 \mathrm{~g}$ ) were captured by local fishermen from the rocky subtidal zone at Helgoland (North Sea, 54 $11.3^{\prime} \mathrm{N}, 7^{\circ} 54.0^{\prime} \mathrm{E}$ ). The animals were placed individually into tanks $(49 \times 79 \mathrm{~cm}$, filled to a depth of $20 \mathrm{~cm}$ ) with running sea water and maintained at ambient water temperature, at ca. $31 \mathrm{psu}$ salinity, and under a natural light-dark cycle. The adult females were fed with a mixture of easily available crustaceans (Carcinus maenas Linnaeus, 1758, Crangon spp., Liocarcinus spp.) and small fish (Myoxocephalus scorpius Linnaeus, 1758, Pholis gunellus Linnaeus, 1758, Pleuronectes platessa Linnaeus, 1758). Actively swimming larvae were collected in the morning after hatching from tanks with ovigerous females, individually transferred to $70 \mathrm{ml}$ cylindrical glass bowls and acclimated to the experimental temperature. The larvae were maintained at a constant water temperature of $18^{\circ} \mathrm{C}$, ca. 31 psu salinity, and under an artificial 12:12 h light-dark cycle. Water and food (30 freshly hatched Artemia sp. nauplii per lobster, cysts from Sander's Brine Shrimp Company) were changed daily.

\section{Phototaxis and vertical distribution}

The first series of experiments was performed with differently aged Zoea I, II, and III larvae, i.e. Zoea I: freshly hatched, one day, two days and three days after hatching; Zoea II and III: freshly moulted, one day, two days and three days after moulting. The larvae were examined with respect to their behavioural responses to different types of illumination.

The experiments were conducted in four circularly arranged, transparent perspex cylinders (height: $100 \mathrm{~cm}$, diameter: $20 \mathrm{~cm}$ ), filled with sea water of $18^{\circ} \mathrm{C}$. A light bulb was positioned alternatively above the top or beneath the bottom of this group of cylinders. The light intensity was set so that it corresponded to the mean photon flux density in Helgoland waters (in July: $143 \mu \mathrm{mol} \mathrm{m}^{-2} \mathrm{~s}^{-1}$ at $2 \mathrm{~m}$ depth; Lüning \& Dring 1979). Light intensity was $50 \mu \mathrm{mol} \mathrm{m}^{-2} \mathrm{~s}^{-1}$ at the lit end (measured directly in front of the light source) of the water columns, and
$0.6 \mu \mathrm{mol} \mathrm{m} \mathrm{m}^{-2} \mathrm{~s}^{-1}$ at $1 \mathrm{~m}$ distance from the source of light (white incandescent light of 380-750 nm, measured with a Quantum irradiance meter: Quantum-Sensor LI-190SA, Licor Data Logger LI1400). No other light sources were allowed to interfere. The larvae were fed $1 \mathrm{~h}$ before the experiments started. All experiments were conducted at the same time of day (start at 9 am, i.e. $3 \mathrm{~h}$ after change from 'night-time' to 'daytime').

For each run of experiment, the four cylinders were equipped each with four larvae of the same age (in total 16 larvae). More than four larvae per column complicated the determination of the larval position in the column and would have increased loss by cannibalism. Four larvae per column was the optimum density found to prevent any interaction.

After transfer into the cylinders, the larvae were allowed to acclimate for $20 \mathrm{~min}$ in darkness. Then the light was positioned on the top of the cylinders and turned on. Thirty minutes later, the vertical distribution of the larvae within the water columns was determined in steps of $10 \mathrm{~cm}$ : $0-10 \mathrm{~cm}$, 10-20 cm, etc., and the light was turned off. After 30 min of darkness, the pattern of vertical distribution was determined again under red light. Red light did not disturb lobsters in their behaviour (Foxon 1934; Weiss et al. 2006). Thereafter the light was placed beneath the cylinders and turned on for another $30 \mathrm{~min}$. A subsequent recording of the vertical larval distribution terminated the experimental run. The larvae were used for one run only. The larval behaviour was considered as positive phototaxis if larvae moved actively towards the light stimulus, and as negative phototaxis if larvae moved away from the source of light.

\section{Sinking rate}

The second series of experiments was performed with all three larval stages (Zoea I, II, and III) to determine the sinking rate of dead larvae. To kill the larvae, specimens were placed carefully with tweezers into an Eppendorf cap filled with $200 \mu \mathrm{l}$ seawater, and were shock-frozen at $-80^{\circ} \mathrm{C}$ for a few minutes. After animals were dead, they were defrosted carefully at the experimental temperature of $18^{\circ} \mathrm{C}$. Thereby, the larvae were kept intact and the process did not change body fluid osmolality. Subsequently, the sinking rate was directly tested by placing an individual dead larva $(n=10)$ at the water surface of the experimental cylinder, as described above for live specimens. The time was measured for the individual larva to sink the $100 \mathrm{~cm}$ water column to the bottom of the cylinder. 


\section{Vertical swimming speed}

The third series of experiments was performed with newly hatched Zoea I larvae only. It was conducted to determine the vertical swimming speed in response to white light in a cylinder, as described above. In preliminary studies the swimming speed of larvae was also tested in an experimental cylinder according to Jacoby (1982). The vertical swimming speed could not be determined for Zoeae II and III, because larvae of these stages did not swim directly towards the light source and the method was thus abandoned.

An individual larva $(n=10)$ was placed into the cylinder at a water temperature of $18^{\circ} \mathrm{C}$. The bottom of the cylinder was lit and the time was measured for the individual larva to swim the $100 \mathrm{~cm}$ straight without stopping or turning. The swimming speed of newly hatched larvae was calculated as the difference between the swimming speed measured and the sinking rate in $\mathrm{cm} \mathrm{s}^{-1}$.

\section{Rheotaxis and horizontal swimming ability}

The fourth series of experiments was performed with all three larval stages (Zoea I, II, and III). It was conducted to determine the larval responses to current stimulation. Previous studies served as comparison to optimize procedures (Ennis 1986; Shirley \& Shirley 1988).

Larvae of stage I $(n=32)$, II $(n=35)$ and III $(n=$ 40) of different female lobsters were used and raised as described above. The rheotactic responses and the swimming ability of individual larvae were observed in a horizontal flow channel (length $=52 \mathrm{~cm}$, width $=5.5 \mathrm{~cm}$, water level $=14 \mathrm{~cm}$ ) at a water temperature of $18^{\circ} \mathrm{C}$. The material of the channel wall consisted of black PVC. A funnel-shaped construction was at one end of the flow channel in order to concentrate the incoming current evenly into the channel. A pump maintained a closed circuit at $3.2 \pm 0.3 \mathrm{~cm} \mathrm{~s}^{-1}$. The flow channel was not covered to allow observation. The set-up was illuminated by a bulb with diffuse white light. The light source was positioned $1 \mathrm{~m}$ above the experimental channel and the light intensity was $50 \mu \mathrm{mol}$ $\mathrm{m}^{-2} \mathrm{~s}^{-1}$ (white incandescent light of $380-750 \mathrm{~nm}$, measured with a Quantum irradiance meter: Quantum-Sensor LI-190SA, Licor Data Logger LI1400). The surface flow velocity in the channel was determined using polystyrene balls. The horizontal swimming ability of the larvae and their positioning in the flow channel (near the surface or near the bottom) were determined for all individual larvae by observation from above.
A single larva was positioned at the beginning of the flow channel. The time taken by the larva to pass through the channel was measured. Rheotaxis was positive if the larvae were oriented in the direction of the current flow. The horizontal swimming ability was calculated as the difference between the water current and the drift velocity of the larvae measured.

\section{Statistics}

Statistical analyses were performed according to Sokal and Rohlf (1995). Data were presented as the mean and standard deviation (SD) of replicates. The tests were performed with the computer programs SigmaStat 2.03 (SPSS) and Statistica 7.1 (StatSoft). The data were tested for normal distribution with the Kolmogorov-Smirnov test. If normal distribution failed, a Mann-Whitney $t$-test was applied. The vertical distributions of the larvae were subjected to a four factorial analysis of variance (ANOVA) and the sinking rate and vertical swimming speed were subjected to a one-way analysis of variance (ANOVA) followed by a Tukey's multicomparison test at a significance level of $\alpha=0.05$. To test the differences in the positioning of larvae in the flow channel, pairwise comparisons by $\mathrm{Chi}^{2}$-Test were performed. Statistical differences $(P<0.05)$ of data sets in tables were indicated by different letters.

\section{Results}

\section{Phototaxis and vertical distribution}

Preliminary experiments had shown that the larval distributions were neither influenced by red light nor of the position of the light source (i.e. light from the top and then light from the bottom and the other way around). At the beginning of each experimental run and after their adaptation in the dark phase, the larvae were distributed just the same as after the experimental run in the darkness, i.e. their initial start position corresponded to their position in darkness depicted in Figures 1, 2, and 3 , middle column of diagrams, respectively. When the light was turned on, larvae always responded by swimming actively. The larvae reacted directly to the change of the experimental light regime and the adaptation time of $30 \mathrm{~min}$ stabilized the distribution.

The four factorial analysis of variance with the independent factors light, water layer, larval age and larval stage showed significant effects $(P=0.012)$ on vertical distribution (Table I). The multi-comparison test showed the following results. 
Zoea I, light from top
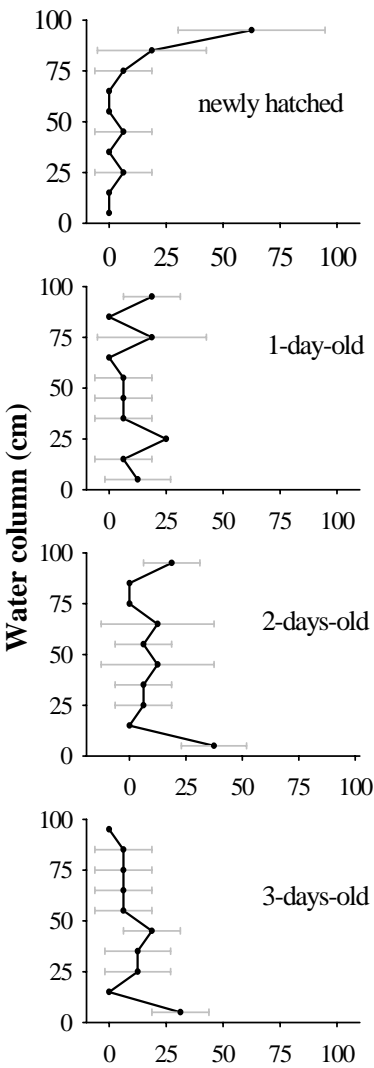

Zoea I, darkness
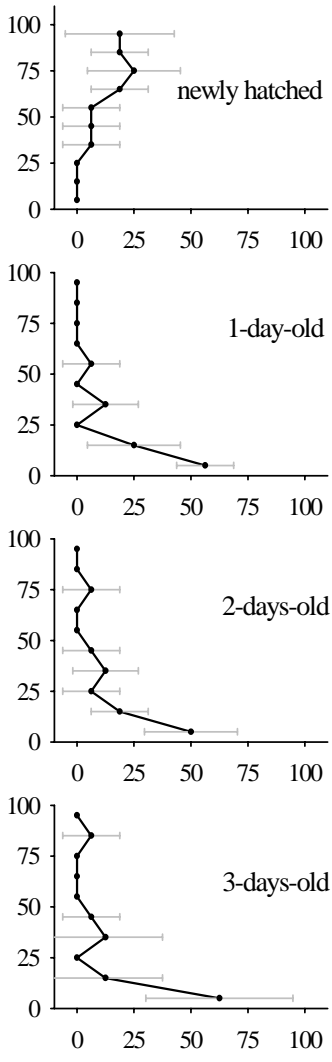

Distribution $(\%)$
Zoea I, light from bottom
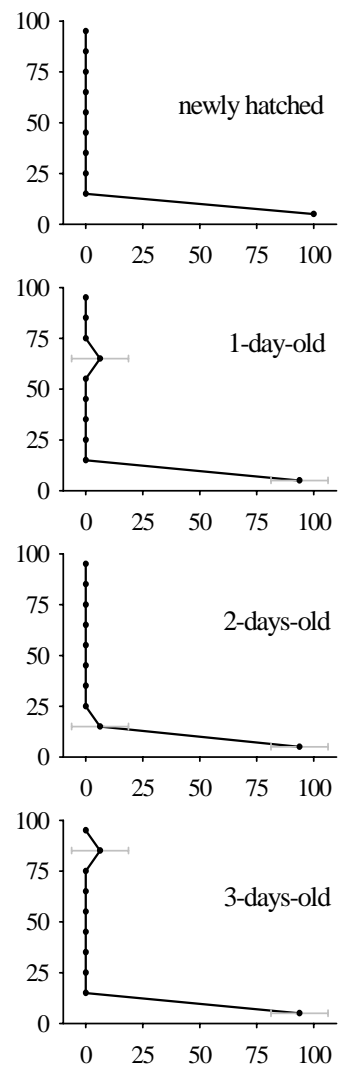

Figure 1. Vertical distribution (\%, mean \pm SD) of Zoea I larvae (Homarus gammarus) of different ages in a water column (height: $100 \mathrm{~cm}$, diameter: $20 \mathrm{~cm}$ ) at different types of illumination (light from the top, darkness, light from the bottom).

\section{Zoea I (Figure 1)}

Light from top: The newly hatched larvae were significantly $(P<0.0001)$ more often distributed in the uppermost $10 \mathrm{~cm}$ of the water column $(90-100 \mathrm{~cm})(62 \pm 32 \%)$ than below $(0-90 \mathrm{~cm})$. The older the larvae, the more larvae were found in the lower parts of the cylinder $(P<0.05)$.

Darkness: Newly hatched larvae were evenly distributed in the upper half of the cylinder $(P=0.0749)$. However, older larvae were more often found in the lower parts of the cylinder $(P<0.0001)$ and more than half of the larvae $(50-63 \%)$ were distributed near the bottom. Light from bottom: Almost all larvae $(95 \pm 3 \%)$ stayed near the bottom $(P<0.0001)$.

\section{Zoea II (Figure 2)}

Light from top: Newly moulted as well as 1- and 2-day-old Zoea II stages were evenly distributed in the water column. However, half of the 3-day-old larvae $(50 \pm 27 \%)$ were distributed near the bottom $(P<0.0001)$.
Darkness: Newly moulted and 1-day-old larvae were evenly distributed in the water column $(P>0.05)$. However, more than half of the 2 - and 3 -day-old larvae $(63 \pm 23 \%)$ were situated near the bottom $(P<0.0001)$.

Light from bottom: Independent of age, almost all larvae $(94 \pm 6 \%)$ were distributed near the bottom $(P<0.0001)$.

\section{Zoea III (Figure 3)}

In this stage, the distribution pattern was independent of larval age (newly moulted, 1-, 2- and 3-dayold Zoea III).

Light from top: A quarter of the larvae $(27 \pm 21 \%)$ was always distributed in the uppermost layer (90$100 \mathrm{~cm}$ ) of the cylinder, and about half the larvae $(52 \pm 28 \%)$ stayed near the bottom $(P<0.0001)$.

Darkness: Almost all larvae $(84 \pm 16 \%)$ were distributed near the bottom $(P<0.0001)$.

Light from bottom: Almost all larvae $(82 \pm 18 \%)$ were found near the bottom $(P<0.0001)$. 
Zoea II, light from top
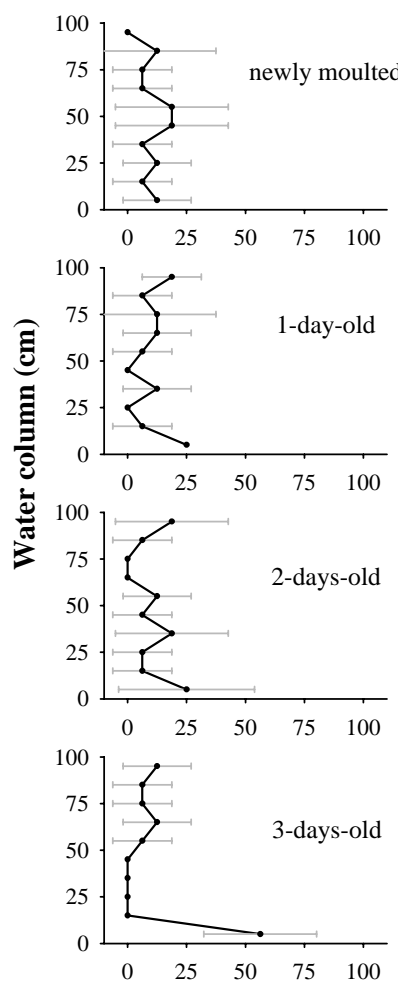

Zoea II, darkness
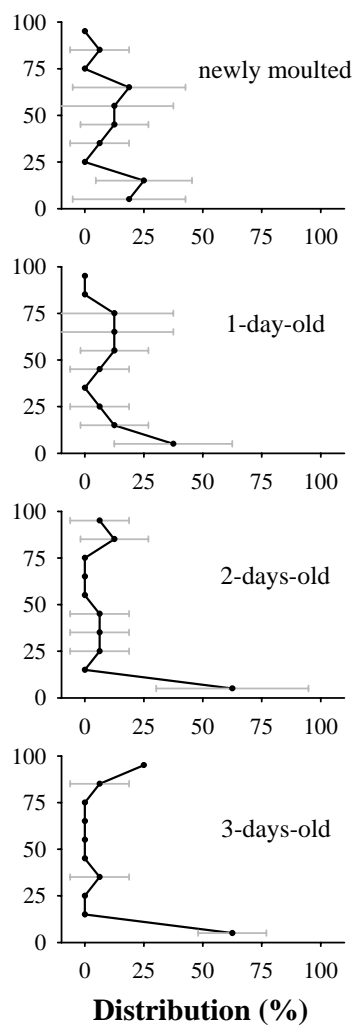

Zoea II, light from bottom
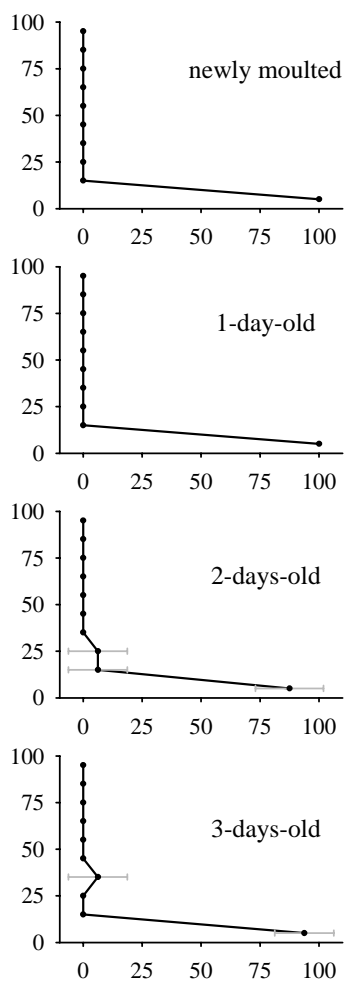

Figure 2. Vertical distribution (\%, mean \pm SD) of Zoea II larvae (Homarus gammarus) of different ages in a water column (height: $100 \mathrm{~cm}$, diameter: $20 \mathrm{~cm}$ ) at three different types of illumination (light from the top, darkness, light from the bottom).

\section{Sinking rate}

The sinking rate of Zoea stage I $\left(1.7 \pm 0.1 \mathrm{~cm} \mathrm{~s}^{-1}\right)$ was significantly different (ANOVA, $P<0.001$ ) from those of Zoea II and III $(2.2 \pm 0.1$ and $2.3 \pm$ $0.2 \mathrm{~cm} \mathrm{~s}^{-1}$, respectively), and there was no difference between stages II and III larvae.

\section{Vertical swimming speed}

Newly hatched larvae (Zoea I) swam directly downwards along the $100 \mathrm{~cm}$ to the light source with a measured velocity of $4.6 \pm 0.5 \mathrm{~cm} \mathrm{~s}^{-1}$. The sinking rates of Zoea stage I were deducted from the vertical swimming speed measured and the swimming velocities of the larvae were averaged at $2.9 \pm 0.5 \mathrm{~cm} \mathrm{~s}^{-1}$.

\section{Rheotaxis and horizontal swimming ability}

All larvae attempted to swim against the flow and none could maintain position against the current $\left(3.2 \pm 0.3 \mathrm{~cm} \mathrm{~s}^{-1}\right)$. However, the larvae turned immediately frontally to the oncoming current. The horizontal swimming ability of all larvae increased with stage from $0.7 \pm 1.0 \mathrm{~cm} \mathrm{~s}^{-1}$ (Zoea I) to about $1.5 \pm 0.9 \mathrm{~cm} \mathrm{~s}^{-1}$ (Zoea II) and $2.2 \pm 0.7 \mathrm{~cm} \mathrm{~s}^{-1}$ (Zoea III) (Table II). The difference between all larval stages (Zoea I, II, and III) was statistically significant $(P<0.001)$.

In the water channel, only newly hatched larvae swam mainly near the surface. The $\mathrm{Chi}^{2}$-Test showed highly significant differences for all pairwise combinations of the data $(P<0.001)$. The percentage of larvae swimming near the bottom increased with stage (Figure 4). Seven percent of stage I larvae stayed near the bottom, $40 \%$ of those of stage II and $78 \%$ of those of stage III.

\section{Discussion}

\section{Phototaxis and vertical distribution}

In the present study, newly hatched lobster larvae showed a marked positive phototaxis, starting already at the lowest light intensity of $0.6 \mu \mathrm{mol} \mathrm{m} \mathrm{m}^{-2}$ $\mathrm{s}^{-1}$. The experimental light intensities were within the range measured in Helgoland waters (in July: $143 \mu \mathrm{mol} \mathrm{m}^{-2} \mathrm{~s}^{-1}$ at $2 \mathrm{~m}$ depth and decreases to $0.7 \mu \mathrm{mol} \mathrm{m}^{-2} \mathrm{~s}^{-1}$ at $15 \mathrm{~m}$ depth (Lüning \& Dring 1979)). Furthermore, the visual pigment absorption maxima of 27 species of benthic crustaceans from semi-terrestrial, estuarine and coastal areas have values ranging from 483 to $516 \mathrm{~nm}$ (Forward et al. 
Zoea III, light from top
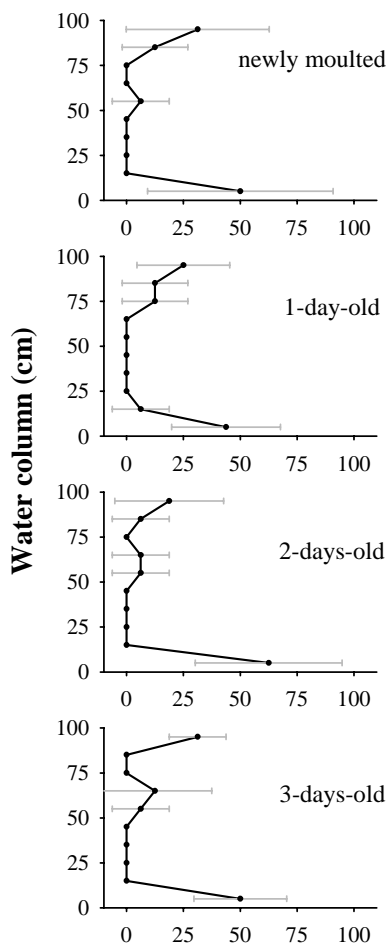

Zoea III, darkness
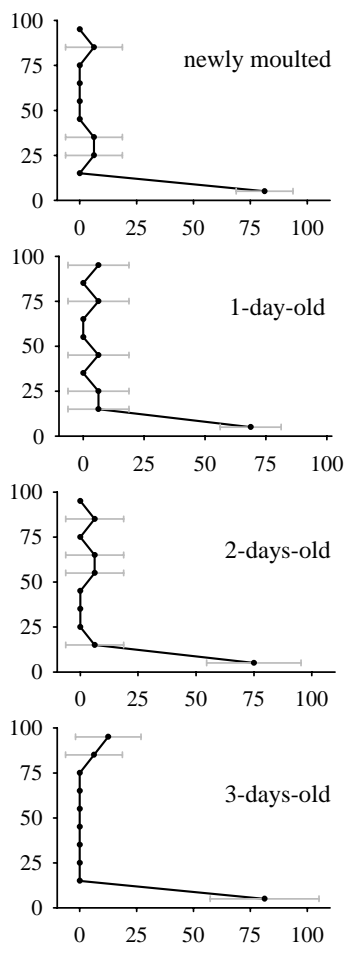

Distribution (\%)
Zoea III, light from bottom
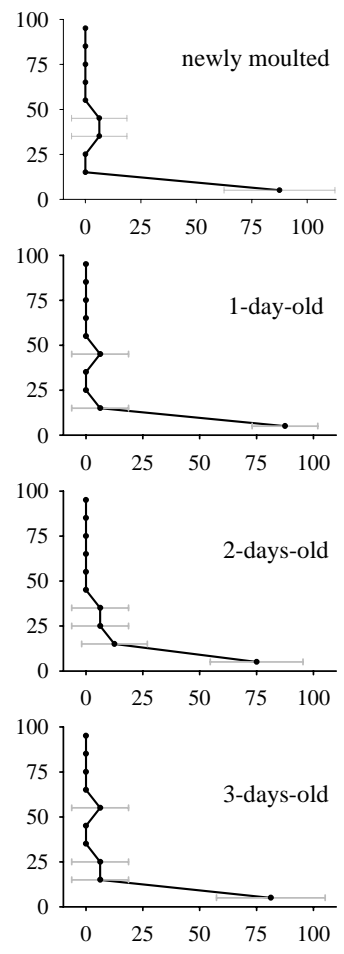

Figure 3. Vertical distribution (\%, mean \pm SD) of Zoea III larvae (Homarus gammarus) of different ages in a water column (height: $100 \mathrm{~cm}$, diameter: $20 \mathrm{~cm}$ ) at three different types of illumination (light from the top, darkness, light from the bottom).

Table I. The vertical distribution of lobster larvae (Zoea I, II, and III) of Homarus gammarus was observed in a water column (0-100 cm) under three different types of illumination (light from the top of the cylinder, in the darkness, light from the bottom). Four replicate experiments were run with four larvae each. $d f=$ degrees of freedom, $S S=$ sum of squares, $M S=$ mean squares, $F=$ variance ratio, $p=$ probability of rejecting a correct null hypothesis $(P \leq 0.05)$.

\begin{tabular}{|c|c|c|c|c|c|}
\hline \multirow[b]{2}{*}{ Source of variation } & \multicolumn{5}{|c|}{ Analysis of variance } \\
\hline & $d f$ & $S S$ & $M S$ & $F$ & $p$ \\
\hline \multicolumn{6}{|l|}{ Main effects } \\
\hline Stage $(S)$ & 2 & 6.1 & 3.0 & 0.024 & 0.9767 \\
\hline Light/Dark $(L D)$ & 2 & 0.9 & 0.4 & 0.003 & 0.9966 \\
\hline Ages $(A)$ & 3 & 1.3 & 0.4 & 0.003 & 0.9997 \\
\hline Water layers $(W)$ & 9 & $407,326.8$ & $45,258.5$ & 351.886 & $<0.0001$ \\
\hline \multicolumn{6}{|c|}{ First-order interactions } \\
\hline $\mathrm{LD} \times \mathrm{S}$ & 4 & 4.3 & 1.1 & 0.008 & 0.9999 \\
\hline $\mathrm{A} \times \mathrm{LD}$ & 6 & 2.6 & 0.4 & 0.003 & 1.0000 \\
\hline $\mathrm{A} \times \mathrm{S}$ & 6 & 7.8 & 1.3 & 0.010 & 1.0000 \\
\hline $\mathrm{S} \times \mathrm{W}$ & 18 & $10,002.6$ & 555.7 & 4.321 & $<0.0001$ \\
\hline $\mathrm{LD} \times \mathrm{W}$ & 18 & $102,117.2$ & $5,673.2$ & 44.109 & $<0.0001$ \\
\hline $\mathrm{A} \times \mathrm{W}$ & 27 & $10,549.9$ & 390.7 & 3.038 & $<0.0001$ \\
\hline \multicolumn{6}{|c|}{ Second-order interactions } \\
\hline $\mathrm{A} \times \mathrm{LD} \times \mathrm{S}$ & 12 & 23.4 & 2.0 & 0.015 & 1.0000 \\
\hline $\mathrm{LD} \times \mathrm{S} \times \mathrm{W}$ & 36 & $21,393.2$ & 594.3 & 4.620 & $<0.0001$ \\
\hline $\mathrm{A} \times \mathrm{LD} \times \mathrm{W}$ & 54 & $14,303.0$ & 264.9 & 2.059 & $<0.0001$ \\
\hline $\mathrm{A} \times \mathrm{S} \times \mathrm{W}$ & 54 & $16,407.1$ & 303.8 & 2.362 & $<0.0001$ \\
\hline \multicolumn{6}{|c|}{ Third-order interactions } \\
\hline $\mathrm{A} \times \mathrm{LD} \times \mathrm{S} \times \mathrm{W}$ & 108 & $18,822.0$ & 174.3 & 1.355 & 0.0120 \\
\hline
\end{tabular}


Table II. The drift velocity ( $\mathrm{cm} \mathrm{s}^{-1}$, mean \pm SD) of drift bodies and of the larvae stages (Zoea I, II, and III) of Homarus gammarus were measured in a horizontal flow channel. The horizontal swimming abilities were calculated as the difference of current velocity and drift velocity of larvae.

\begin{tabular}{lccc}
\hline & & $\begin{array}{c}\text { Drift velocity } \\
\left(\mathrm{cm} \mathrm{s}^{-1}\right)\end{array}$ & $\begin{array}{c}\text { Swimming } \\
\text { ability } \\
\left(\mathrm{cm} \mathrm{s}^{-1}\right)\end{array}$ \\
\hline Drift body & 16 & $3.2 \pm 0.3^{\mathrm{a}}$ & \\
Zoea I & 32 & $2.5 \pm 1.0^{\mathrm{b}}$ & $0.7 \pm 1.0^{\mathrm{a}}$ \\
Zoea II & 35 & $1.7 \pm 0.9^{\mathrm{c}}$ & $1.5 \pm 0.9^{\mathrm{b}}$ \\
Zoea III & 40 & $1.0 \pm 0.8^{\mathrm{d}}$ & $2.2 \pm 0.7^{\mathrm{c}}$ \\
\hline
\end{tabular}

Different superscripts denote statistically significant differences (one-way ANOVA and paired comparisons post hoc test $(P=0.05)) . N=$ Number of measured lobsters.

1988). Previous studies have shown that crustacean larvae of Rhithropanopeus harrisii (Gould, 1841) responded positively to light intensities between 0.0006 and $1 \mathrm{~W} \mathrm{~m}^{-2}$, measured at $500 \mathrm{~nm}$ (i.e. 0.003 to $4 \mu \mathrm{mol} \mathrm{m}^{-2} \mathrm{~s}^{-1}$ ) (Forward 1974). We used light at a broad range of 380-750 nm wavelengths. Accordingly, the experimental light must have been well discernible by the lobster larvae.

Under laboratory conditions newly hatched larvae always stayed at the surface and swam directly towards any light source in accordance with observations of Neil et al. (1976), Dunn \& Shelton (1983) and Watt \& Arthur (1996), who reported that larvae after hatching always swim towards the sea surface. In our experiments, the newly hatched lobster larvae reacted immediately to light - irrespective of the direction - even if it came from the bottom and responded with a downward vertical swimming speed of about $4-5 \mathrm{~cm} \mathrm{~s}^{-1}$ (including the sinking rate of $1.7 \mathrm{~cm} \mathrm{~s}^{-1}$ ). The same positive phototatic reaction was observed in the first larval stage of the

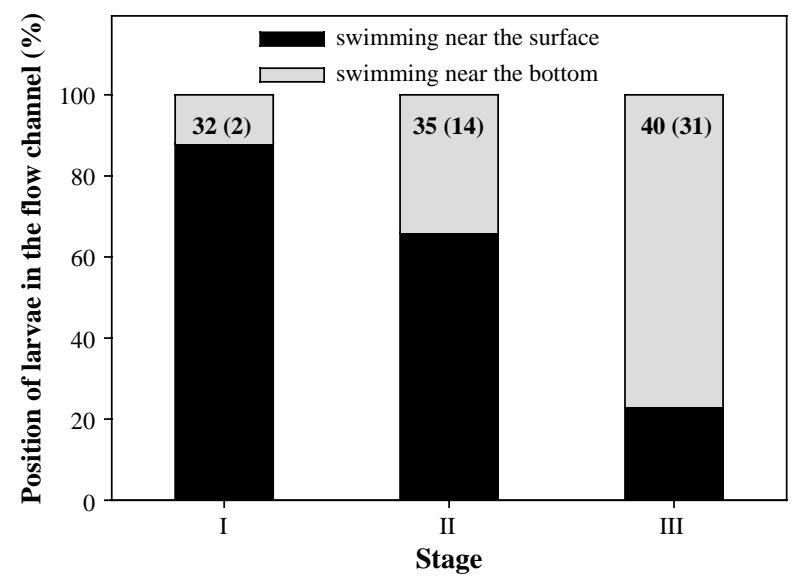

Figure 4. Vertical position of larvae (Zoea I, II, and III) of Homarus gammarus during passage through a flow channel. The total number of individuals observed is given for each Zoea stage (in parentheses those observed near the bottom).
American lobster, Homarus americanus (Hadley 1908). Furthermore, other crustacean larvae respond equally in their first Zoea stage, e.g. Cancer pagurus Linnaeus, 1758, Carcinus maenas, Macropipus spp. (Sulkin 1984), and the first larval stage of Galathea strigosa (Linnaeus, 1761) and Galathea dispersa (Bate, 1859) reached maximum swimming speeds of approximately $2 \mathrm{~cm} \mathrm{~s}^{-1}$ (Foxon 1934).

In the field, Dunn \& Shelton (1983) and Nichols (1984) found newly hatched larvae of the European lobster always at the surface. In the present study, we found a marked positive response to light only in newly hatched Zoea I larvae, which swam straight towards the light source whether this was placed on the top or at the bottom. With progressing larval age and stage, this positive response to light rapidly disappeared, and the larvae were oriented predominantly to the deeper layers irrespective of the type of illumination (light from the top, light from the bottom, darkness). Additionally, the low sinking rate of Zoea I facilitates their positive phototactic behaviour before they tend to swim to the deeper layers in the later stages. Moreover, Hadley (1908) found that phototactic responses of larvae of $H$. americanus changed both within and between each stage. He reported that larvae in early second and third stages are negatively phototactic, but again respond positively to light shortly ( $\sim$ one day) before moulting. A shift from positive to negative phototaxis may explain behavioural changes in many pelagic larvae (Forward 1974; Shirley \& Shirley 1988), but apparently this does not apply to the larvae of Homarus gammarus. With decreasing positive response to light, larvae accumulated near the bottom even if the light came from just this direction. Ennis (1973) reported that the depth regulation of the first three Zoea stages responded to water pressure changes and that overhead light reduced the reaction time at low water pressure, i.e. at shallow depths.

From an ecological point of view, the positive response to light of the first larval stage may be a means to promote animal dispersal at the rocky bottom around the island of Helgoland, and the early and abrupt change in larval behaviour reduces the threat of drifting away from this suited environment.

\section{Current and swimming ability}

Our experiments showed that with successive larval stages the ability of larvae increased to swim in the current, resulting from an increase in horizontal swimming ability from $0.7 \mathrm{~cm} \mathrm{~s}^{-1}$ (Zoea I) to $1.5 \mathrm{~cm} \mathrm{~s}^{-1}$ (Zoea II) and ultimately to $2.2 \mathrm{~cm} \mathrm{~s}^{-1}$ (Zoea III). This is the same order of magnitude as in 
other decapod crustacean larvae which show swimming speeds ranging from 0.1 to $3.3 \mathrm{~cm} \mathrm{~s}^{-1}$. Equally, the locomotion varies with the age of the larva (see Chia et al. 1984). In our experiment the percentage of larvae swimming near the bottom increased with stage during the drift through the current channel. This change of locomotion abilities during larval development of lobster larvae facilitates the active movement in currents, i.e. positive rheotactic behaviour, and may help to prevent larvae to be swept downstream by the current in the later stages. However, Ennis (1986) observed that larvae of $H$. americanus can hold their position only for few minutes in a current of $2 \mathrm{~cm} \mathrm{~s}^{-1}$ and the response is relatively weak to swim against the current but increases in Stage IV.

\section{Larval recruitment around the island of Helgoland}

The habitat of the Helgoland lobster population is limited at only about $33 \mathrm{~km}^{2}$ and is isolated from other hard-bottom areas, so that the exchange with neighbouring populations is low (Ulrich et al. 2001). Nevertheless, the Helgoland habitat is exposed to strong tidal currents with a velocity of up to $102 \mathrm{~cm}$ $\mathrm{s}^{-1}\left(2 \mathrm{~nm} \mathrm{~h}^{-1}\right)$. The tides shift the water mass during a half tide at about $5-10 \mathrm{~nm}$ in a tidal ellipse around the island and the resulting residual current is low with a mean of $10 \mathrm{~cm} \mathrm{~s}^{-1}\left(0.2 \mathrm{~nm} \mathrm{~h}^{-1}\right)$ (Hickel 1972).

Despite the inherent difficulties associated with any transfer of behavioural data from the laboratory to the field, the present results may give an idea how the life history of $H$. gammarus allows for the existence of a self-sustaining lobster stock at Helgoland. During the early phase of the Zoea I stage, a strong positive phototaxis results in a preference of the larvae for the uppermost water layers. Here, the risk of being swept away is highest. In summer, the development of Zoea I larvae takes about 4 days (Schmalenbach in prep.), roughly corresponding to the critical drift phase. However, the water masses circle the island several times (Hickel 1972) and therefore the probability may be high that the larvae remain above the rocky base of the island of Helgoland. At a small scale, a current induced change of local habitat is facilitated which may be seen as an ecological advantage. However, the older larvae tend to hold their position near the bottom where current speeds are considerably lower and may thus be able to remain in the favoured habitat. In contrast, Scarratt (1964) suggested that surface drift carries the larvae of $H$. americanus from parent stock to possible areas of settlement. This may be seen as an advantage in a more homogeneous environment.
Generally, recruitment of the lobster population is dependent on stock size, density of ovigerous females, survival and development time of larvae, and fishery mortality. At Helgoland, legislative regulations may have prevented a complete extinction of the local population. These regulations include the establishment of a special protection area, an agreement on a minimum size $(11 \mathrm{~cm}$ carapace length, including rostrum) for landed lobsters, a ban on landings of ovigerous females, and a closed season of 1.5 month in July-August (Ministerium für Landwirtschaft 1981, 1999). We suspect though that these measures did not result in the population's recovery and that it still remains below a critical threshold which is necessary for the population to recover at a large scale.

The knowledge about the positioning of larvae around the island of Helgoland helps to understand the life history of the Helgoland lobster population and may be helpful in assessing the development of a future stock enhancement programme. Harding et al. (2005) used field observations of the lobster larval distribution in the Gulf of Maine for modelling larval drift to estimate probable source areas for settling of stage IV post-larvae. Furthermore, there are different lobster larval transport models which combine oceanographic processes and behavioural traits (Katz et al. 1994; Incze \& Naimie 2000; Annis et al. 2007). The life history data gained will be used to parameterize and optimize a set of models. These can be used to assess the status and to forecast the recruitment and development of the local lobster population allowing further managerial measures in order to establish a sustainable fishery at Helgoland and other areas of lobster occurrence.

\section{Acknowledgements}

This work is part of the $\mathrm{PhD}$ thesis of I.S. This study was supported financially by the Ministry of Fisheries and Agriculture of the State of SchleswigHolstein, Germany, project no.: 1317-11-68511005. Thanks are due to the local fishermen for providing berried females and to Michael Janke for technical support and help in rearing and keeping of the female lobsters. We want to thank Professor HeinzDieter Franke for his helpful comments on the study and the manuscript. We also thank the two anonymous reviewers for their valuable comments and suggestions.

\section{References}

Anger K, Harms J. 1994. The Helgoland lobster: A disappearing island population. The Lobster Newsletter 7(2):11-2. 
Annis ER, Incze LS, Wolff N, Steneck RS. 2007. Estimates of in situ larval development time for the lobster, Homarus americanus. Journal of Crustacean Biology 27(3):454-62.

Bannister RCA. 1986. Assessment and population dynamics of commercially exploited shellfish in England and Wales. In: Jamieson GS, Bourne N, editors. North Pacific Workshop on Stock Assessment and Management of Invertebrates. Canadian Special Publication of Fisheries and Aquatic Science 92: 182-94.

Browne RM, Mercer JP, Duncan MJ. 2001. An historical overview of the Republic of Ireland's lobster (Homarus gammarus Linnaeus) fishery, with reference to European and North American (Homarus americanus Milne Edwards) lobster landings. Hydrobiologia 465:49-62.

Chia F-S, Buckland-Nicks J, Young CM. 1984. Locomotion of marine invertebrate larvae: A review. Canadian Journal of Zoology 62:1205-22.

Deutscher Fischereiverein und die ihm angeschlossenen Organisationen in Schleswig-Holstein Mecklenburg-Vorpommern, Hamburg, Bremen und Niedersachsen. 1980-2007. Fischerblatt-Mitteilungen für die Kutter- und Küstenfischerei, Hamburg. 50 pages.

Dow RL. 1980. The clawed lobster fisheries. Chapter 8. In: Cobb JS, Phillips BF, editors. The Biology and Management of Lobsters II. Ecology and Management. New York: Academic Press. p 265-316.

Dunn J, Shelton RGJ. 1983. Observations on lobster, Homarus gammarus (L.), larvae held in a Loch Ewe enclosure. ICES CM 1986/L, 30:1-6.

Ennis GP. 1973. Behavioral responses to changes in hydrostatic pressure and light during larval development of the lobster Homarus gammarus. Journal of the Fisheries Research Board of Canada 30:1349-60.

Ennis GP. 1983. The effect of wind direction on the abundance and distribution of decapod crustacean larvae in a Newfoundland nearshore area. Canadian Technical Report of Fisheries and Aquatic Sciences 1138: 19 pages.

Ennis GP. 1986. Swimming ability of larval American lobsters, Homarus americanus, in flowing water. Canadian Journal of Fisheries and Aquatic Sciences 43:2177-83.

Ennis GP. 1995. Larval and postlarval ecology. Chapter 3. In: Factor JR, editor. Biology of the Lobster Homarus americanus. San Diego: Academic Press. p 23-46.

Fishery Statistics 1950-2006. Eurostat Database of European Commission. Available at: http://epp.eurostat.ec.europa.eu.

Forward RB Jr. 1974. Negative phototaxis in crustacean larvae: Possible functional significance. Journal of Experimental Marine Biology and Ecology 16:11-7.

Forward RB Jr. 1989. Depth regulation of larval marine decapod crustaceans: Test of a hypothesis. Marine Biology 102: 195-201.

Forward RB Jr, Cronin TW, Douglass JK. 1988. The visual pigments of crabs. Journal of Comparative Physiology A: Neuroethology, Sensory, Neural, and Behavioral Physiology 162(4):479-90.

Foxon GEH. 1934. Notes on the swimming methods and habits of certain crustacean larvae. Journal of the Marine Biological Association of the UK 19:829-49.

Goemann O. 1990. 'Echt' Helgoländer Hummer. Oldenburg: Kohlrenken. 82 pages.

Greve W, Reiners F, Nast J, Hoffmann S. 2004. Helgoland Roads meso- and macrozooplankton time-series 1974 to 2004: Lessons from 30 years of single spot, high frequency sampling at the only off-shore island of the North Sea. Helgoland Marine Research 58:274-88.
Hadley PB. 1908. The behaviour of the larval and adolescent stages of the American lobster (Homarus americanus). Journal of Comparative Neurology 18(3):199-303.

Harding GC, Drinkwater KF, Hannah CG, Pringle JD, Prena J, Loder JW, et al. 2005. Larval lobster (Homarus americanus) distribution and drift in the vicinity of the Gulf of Maine offshore banks and their probable origins. Fisheries Oceanography $14(2): 112-37$.

Harding GC, Drinkwater KF, Vass WP. 1983. Factors influencing the size of American lobster (Homarus americanus) stocks along the Atlantic coast of Nova Scotia, Gulf of St. Lawrence, and Gulf of Maine: A new synthesis. Canadian Journal of Fisheries and Aquatic Science 40:168-84.

Harding GC, Pringle JD, Vass WP, Pearre S Jr, Smith SJ. 1987. Vertical distribution and daily movements of larval lobsters Homarus americanus over Browns Bank, Nova Scotia. Marine Ecology Progress Series 41:29-41.

Harms J, Schilling U, Goemann O. 1995. Der 'Helgoländer Hummer'. Natur und Museum 125(2):33-40.

Hickel W. 1972. Kurzzeitige Veränderungen hydrographischer Faktoren und der Sestonkomponenten in driftenden Wassermassen in der Helgoländer Bucht. Helgoländer Wissenschaftliche Meeresuntersuchungen 23(3):383-92.

Hudon C, Fradette P. 1993. Wind-induced advection of larval decapods into Baie de Laisance (Îles de la Madeleine, Québec). Canadian Journal of Fisheries and Aquatic Sciences 50: 1422-34.

Incze LS, Naimie CE. 2000. Modelling the transport of lobster (Homarus americanus) larvae and postlarvae in the Gulf of Maine. Fisheries Oceanography 9(1):99-113.

Jacoby CA. 1982. Behavioural responses of the larvae of Cancer magister Dana (1852) to light, pressure, and gravity. Marine Behaviour and Physiology 8:267-83.

Johnson MW. 1960. On the dispersal of lobster larvae into the East Pacific barrier (Decapoda, Palinuridea). Fishery Bulletin 72(3):639-47.

Katz CH, Cobb JS, Spaulding M. 1994. Larval behavior, hydrodynamic transport, and potential offshore-to-inshore recruitment in the American lobster Homarus americanus. Marine Ecology Progress Series 103:265-73.

Klimpel J. 1965. Die neuzeitliche Entwicklung der Inselgemeinde Helgoland unter besonderer Berücksichtigung des Fremdenverkehrs. Konstanz: Dr.- u. Verl.-Anst, Konstanz. 264 pages.

Lüning K, Dring MJ. 1979. Continuous underwater light measurement near Helgoland (North Sea) and its significance for characteristic light limits in the sublittoral region. Helgoländer Wissenschaftliche Meeresuntersuchungen 32:403-24.

Makarov RR. 1969. Transport and distribution of decapod larvae in the plankton of the western Kamchatka shelf. Oceanology 9:251-9.

Mileikovsky SA. 1973. Speed of active movement of pelagic larvae of marine bottom invertebrates and their ability to regulate their vertical position. Marine Biology 23:11-7.

Minchin D. 1984. Larvae of the lobster Homarus gammarus (L.) from the plankton of Lough Hyne (Ine), Co. Cork. Irish Naturalists' Journal 21(8):334-6.

Ministerium für Landwirtschaft, Umwelt und ländliche Räume 1981, 1999. Landesverordnung über die Ausübung der Fischerei in den Küstengewässeren (Schleswig-Holsteinische Küstenverordnung - Küfo), Germany. 12 pages.

Neil DM, MacMillan DL, Robertson RM, Laverack MS. 1976. The structure and function of thoracic exopodites in the larvae of the lobster Homarus gammarus (L.). Philosophical Transactions of the Royal Society of London. Series B. Biological Sciences 274:53-68. 
Nichols JH. 1984. The occurrence of lobster larvae (Homarus gammarus L.) in Galway Bay. Irish Naturalists' Journal 21(6):275-8.

Nichols JH, Lawton P. 1978. The occurrence of the larval stages of the lobster Homarus gammarus (Linnaeus, 1758) off the northeast coast of England in 1976. Journal du Conseil Conseil International pour 1'. Exploration de la Mer 38(2):234-43.

Sandifer PA. 1973. Distribution and abundance of decapod crustacean larvae in the York River Estuary and adjacent lower Cheaspeake Bay Virginia, 1968-1969. Cheaspeake Science 14:235-57.

Scarratt DJ. 1964. Abundance and distribution of lobster larvae (Homarus americanus) in Northumberland Strait. Journal of the Fisheries Research Board of Canada 21(4):661-80.

Shirley SM, Shirley TC. 1988. Behavior of red king crab larvae: Phototaxis, geotaxis and rheotaxis. Marine Behaviour and Physiology 13:369-88.

Sokal RR, Rohlf FJ. 1995. Biometry. New York: Freeman and Company. 887 pages.

Sulkin SD. 1984. Behavioral basis of depth regulation in the larvae of branchyuran crabs. Marine Ecology Progress Series 15: 181-205.

Templeman W. 1937. Habits and distribution of larval lobsters (Homarus americanus). Journal of the Biological Board of Canada 3:343-7.

Tully O, Ó Céidigh P. 1987. The seasonal and diel distribution of lobster larvae (Homarus gammarus (Linnaeus)) in the neuston of Galway Bay. Journal du Conseil - Conseil International pour l'Exploration de la Mer 44:5-9.
Tully O, Bell M, O'Leary A, McCarthy A, O’Donovan V, Nee D. 2006. The lobster (Homarus gammarus L.) fishery: Analysis of the resource in 2004/2005. Fisheries Resource Series, Board lascaigh Mhara (Irish Sea Fisheries Board), Dun Laoghaire, Ireland 6: 62 pages.

Ulrich I, Müller J, Schütt C, Buchholz F. 2001. A study of population genetics in the European lobster, Homarus gammarus (Decapoda, Nephropidae). Crustaceana 74(9):825-37.

Van der Meeren GI, Tveite S. 1998. Fishery and management of the lobster (Homarus gammarus) in Norway. In: Van der Meeren GI, Soldal O, editors. The European Lobster Homarus gammarus (L.): Proceedings from the Seminar at Kvitsøy 1995. Fisken og havet 1998, 13. p 72-76.

Walter I, Schmidt M, Buchholz F. 2008. Der Einfluss von Erdöl auf das Verhalten von Hummern. Effekte auf Nahrungssuche und Aggression. VDM Verlag Dr. Müller Aktiengesellschaft \& Co. KG, Saarbruecken. 170 pages.

Watt L, Arthur G. 1996. The improvement of the Shetland lobster fishery through stock enhancement -1 . North Atlantic Fisheries College. Fisheries development note 2: 4 pages.

Weiss HM, Lozano-Alvarez E, Briones-Fourzan P, Negrete-Soto F. 2006. Using red light with fixed-site video cameras to study the behavior of the spiny lobster, Panulirus argus, and associated animals at night and inside their shelters. Marine Technology Society Journal 40(3):86-95.

Editorial responsibility: Franz Uiblein 